\title{
Turkey-Russia Relations After The Cold War Era And The Middle East Policies
}

\author{
Çağatay Fehmi Göker \\ Department of International Relations \\ Kocaeli University, Kocaeli, Turkey
}

\author{
Dr. Ali Poyraz Gürson \\ Associate Professor, Department of International Relations International Law Chair \\ Kocaeli University, Kocaeli, Turkey
}

\begin{abstract}
Ottoman Empire- Tsarist Empire, Turkey-Soviet Union and Turkey- Russia's politic conflict dates back past to present. Tsarist Empire or Soviet Union or Russia Federation's goal, which is "desire to gain access to the warm waters", in other words "Panslavizm" still continues. The ideal for them is that Turkey constituted a threat of all time. Turkey and Soviet Union's relationship alternates between tense and cold. Turkey is allied NATO due to its self-border security. It has regarded Soviet Union as a threat and their relationship are exceedingly tense owing to politic conflict of interest. In the same way, with the world power USSR. Turkey is a threat to NATO for the World power USSR's regional politic factors. However, the relationship between Turkey and Russia has been very improved in time. Today Russia is in the top 10 of the countries that Turkey exports. That is to say, Turkey and Russia's political relationship are more advanced comparing with the past. Although their relations are "warmer" than the past, the two countries' remarks does not match in the Middle East politics. These issues are North Iraq and Kurdish State, PKK and terror Issues, Turkoman, Energy Issues, and the Syria Crisis... This issues especially concern Turkey but Russia follows different politics thus this obstruct constituting 'trust' issue between two countries. Russia really fell down in the Soviet Union's period of regression but it recuperates today. Old foreign affairs minister and the Middle East expert Yevgeni Primakov and ongoing period Putin government has been building "trust" and showing "stability" in a sort of way again and it works for gaining their old power today. Russia has understood that it needs to gather themselves up; by trying to get support from Muslim state for Chechen problem that leads Russia to play an active role in the Middle East and Syria Crisis. At the same time Putin government is planning arms sale which will be a significant economic resource for the mixed zone. Turkey is in the opposite of the Russia in terms of policy as it follows its own which protects its zone's stability. Today the detrimental effects of the conflict reached its peak and there is a war in zone. Besides that, Turkey wants to take the advantage of the power and the authority vacuum in the region in order to be effective power in the zone. Because of this entire situation, Turkey and Russia conflict in terms of politics.
\end{abstract}

Keywords: Turkish-Russian Relations, Jet Crisis, Middle East Policies, Turkey-NATO relations, Syrian Crisis, Kurdish Issue.

Turkey and Russia, two countries that have historically been the enemies, enhanced their relations after the collapse of USSR. After the recovery period, Russia stepped up its regional power with soft power policies. Turkey is an important goal in this regard, both as a geopolitical position and being a member of NATO. In the same period, Turkey also calls upon for developing relations with Russia. Consequently, both sides signed economic treatments. The high level of economic relations between Turkey and Russia has become the most important component of their bilateral multidimensional relations. Trade volume between two 
countries exceeded 25.2 billion Dollars, as of the first 11 month of 2007, making Russia; Turkey is second trading partner after Germany. Russia is now the main source of import for the Turkish economy. Imports from Russia account for about $13 \%$ of overall imports. ${ }^{1}$ Turkey is dependent to Russia in its $60 \%$ of demand in energy. It is a compelling situation for independent Turkey and it should be stretched out.

Although Turkish and Russian relations are enlarged, deepened and multidimensional, there are serious problems between the two countries that are not spoken aloud. After the collapse of USSR, Turkey wants to build bridges between western civilization and Middle Asia and Caucasus post-soviet states. Especially the Turkish origin states are the most significant issues for new Turkish diplomacy. Russia bewares after these emerging developments. Turkey develops its diplomacy with Azerbaijan in the Qarabagh Crisis by standing against Armenia. Russia was supporting Armenia in this Crisis and declared "Moscow wants be arbitrator of this conflict". Russia and Turkey are competitive states in the region and both of them try to gain influence. Turkey wants to make deals with post-Soviet states about oil transportation and natural gas. Russia uses energy as a tool for foreign policy and oppression and wants to preserve its monopoly position, opposes projects that will increase resource diversity and exclude itself ${ }^{2}$. Russia develops projects as counter-moves for Turkish moves in the region. Turkish energy sector is also dependent to Russia and tries to break these shackles.

Meanwhile, Turkey and Russia have other big problems, which are PKK and Kurdish issues. In 1990s, both of these countries were in trouble with radical minority groups. Russia had Chechen problem inside and complainant about Turkish of this group. Turkey has Chechen NGOs and it is oppress for reacting the Turkish government about Russian pressures to Chechens. On the other side, Russia starts supporting minority groups in Turkey, especially Kurdish people. Russia still does not recognize the PKK as a terrorist organization. ${ }^{3}$ Kurds are very crucial for Middle East's future and Russia knows that. While economic and political relations are evolving, both countries have differences of opinions in the regional affairs. Therefore, relations between these two countries are always going to be under the threat of breaking up.

Turkey is using NATO "especially the US" struggle with Russia and its regional policies. Latterly, Turkey and Russia have the crisis of Turkish F-16 shooting down the Russian fighter jet SU-24 in the Turkish Syrian border, because of the violation of Turkish air space. Turkish authorities immediately approached NATO for support, a move that reportedly infuriated Russian President Vladimir Putin, who called the falling down of the plane "a stab in the back." The Russian military claimed that the Turkish action was pre planned-an accusation the Turkish General Staff denied. ${ }^{4}$ Turkey and Russia have economically interdepended to each other. However, in the strategical terms of economic dependence; Turkey has by far away dependence to Russia. It has become visible, when Russia started to economic sanctions to Turkey after the 'the jet crisis'. Turkey's economy influenced a lot from the sanctions. In political terms, Turkey and Russia still do not match in the Middle East policies. These days

\footnotetext{
${ }^{1}$ http://www.mfa.gov.tr/turkey_s-commercial-and-economic-relations-with-russian-federation.en.mfa (accessed January 26, 2017)

2 Özbay Fatih, Soğuk Savaş Sonrası Türkiye-Rusya İlişkileri(1992-2010), “Jeopolitik, Ekonomi-Politik ve SosyoKültürel Araştırmalar Dergisi”, S:4 (2011), S. 35-79.

3 https://tr.wikipedia.org/wiki/PKK\%27yl_terör_örgütü_kabul_eden_ülke_ve_kurulușlar (accessed December 5,2016)

4 https://www.americanprogress.org/issues/security/reports/2016/05/10/137131/the-crisis-in-turkishrussian-relations/, (accessed December 9, 2016)
} 
Turkey supports the Syrian oppositions and the Russia supports the Syrian Regime. So Turkish and Russian relationship has tensed again. Turkey could not get enough support from its NATO allies or US after this situation. Turkish officials frustrated about this situation and demarches its position. Turkish president Erdogan and Russian president Putin's leadership methods are very similar. They have used patriotism in any diplomatic crisis. In beginning of Jet crisis, you can see that easily. Nevertheless, latterly, Turkey could not compete with Russian sanctions and Turkish president Erdogan apologised for fell down Russian jet ${ }^{5}$ in the beginning of June. In the $15^{\text {th }}$ July, Turkey had a failed coup attempt. When this was happening Russian leader, Putin and Russia stand with the elected government and declared "Russia will be with the legal governance". However, most of the Western Countries waited for the ending of the attempt to declare this. Therefore, in that stage, Turkey and Russia rapprochement accelerated. After the failed coup, president Erdogan visited Russia to meet Putin in $9^{\text {th }}$ August. Under these circumstances, Putin had the opportunity to appeal Turkey with Syrian policies. Turkey's intensive situation is continuing after the failed coup; Turkey declares state emergency for fight with inner terrorist organizations and starts "Euphrates Shield" operation for fight outsider terrorist organizations. Putin knows that Turkey has many problems with NATO allies especially the US. Besides, Russia has similar problems with Europe and NATO because of annexation of Crimea. Under these circumstances, Putin could not miss this opportunity to make apart the Turkey that is sixty years ally of NATO from the Western alliance. Now, we will focus Turkey's relations with the US.

Turkey and US are in strategical partnership in regional and international issues against USSR/Russia since 1952. Although Turkey still depends on the United States and other NATO allies for political and strategic support, and has close economic links with the European Union, its increased economic and military self-reliance since the Cold War allows Turkey relatively greater opportunity for an assertive role in foreign policy. ${ }^{6}$ As the partnership continues in Syria against ISIS. In the $15^{\text {th }}$ July, Turkey had experienced a failed coup. Existing challenges for Turkey and tensions in U.S.-Turkey relations have been exacerbate by a failed coup attempt in July 2016 and the ongoing government response. The vigorous response, accompanied by the Turkish parliament's approval of a three-month state of emergency. ${ }^{7}$ Nevertheless, Turkey and Russia remain on opposite sides of the Syrian conflict, and the two states disagree over Russian involvement in Ukraine and other areas. Turkey is also a member of NATO, with historic ties to both Europe and the United States. That means the current reconciliation with Russia will have its limits. ${ }^{8}$ The other significant challenge between Turkey and USA is the Kurdish issue. US's most efficient partner in the frontline against ISIS is "People's Protection Units" (PYD/YPG); oriented from PKK which is known as terrorist organization both by Turkey and US. US's ally organization PYD has become a threat after the city of Menbij captured by YPG from ISIS. Turkey claims to have received a promise from the United States that YPG forces will not occupy territory west of the Euphrates River. ${ }^{9}$ Turkey has dubbed the operation "Euphrates Shield," and presidential spokesman Ibrahim Kalin has stated that it is aimed at neutralizing

\footnotetext{
5 https://www.theguardian.com/world/2016/jun/27/kremlin-says-erdogan-apologises-russian-jet-turkish (accessed December 18, 2016)

6 ZANOTTI Jim and THOMAS Clayton, Turkey: Background and U.S Relaions, Congressional Researh Service, 2016, p.2

7ZANOTTİ Jim and THOMAS Clayton, a.g.e p:2

${ }^{8}$ http://time.com/4608523/turkey-russia-andrey-karlov-assassination/ (accessed January 20, 2017)

9ZANOTTİ Jim and THOMAS Clayton, a.g.e p:29
} 
threats that Turkey perceives from both the Islamic State and the $\mathrm{YPG}^{10}$. Turkey is also on the ground after Euphrates Shield operation and US led coalition has support this operation.

The disturbance of Middle East continues in Syria and the entire world is focused and wondering that when peace and order will come. Nobody can know what will happen in the Middle East. Doyen diplomat Henry A. Kissinger has said, "You can't make war in the Middle East without Egypt and you can't make peace without Syria" ${ }^{11}$. You can easily understand what he expresses by looking at the map of a Middle East. Turkey, Russia and Iran's foreign ministries met in Moscow for organising Astana peace talks between Syrian government and its opposition. All parties declare that Astana talks will be complement Geneva peace talks. ${ }^{12}$ In the meantime, On December 19, a gunman at an art gallery exhibition opening in Ankara killed Russian Ambassador to Turkey Andrey Karlov. ${ }^{13}$ The assassination shocked the world and tested Russian-Turkish relations, but the ties did not break. Turkey and Russia's leaders put on a show of unity. Erdogan and Putin both condemned the attack as a "provocation" designed to undermine relations between the two countries. On Tuesday, a high-level Russian-TurkishIranian summit over the war in Syria went ahead in Moscow as planned. ${ }^{14}$ Turkey and Russia

10 ZAMAN Amberin, "Turkish Troops Enter Syria to Fight ISIS, May also Target U.S.-Backed Kurdish Militia," Woodrow Wilson Center, August 24, 2016.

11 http://www.csmonitor.com/2002/0422/p01s04-wome.html (accessed January 10, 2017)

12 http://www.aljazeera.com.tr/haber/rusya-astana-gorusmeleri-ocak-ayinda (accessed January 13, 2017)

13 https://sputniknews.com/trend/russian_ambassador_karlov_killed_turkey_2016/(accessed January 20, 2017)

14 http://time.com/4608523/turkey-russia-andrey-karlov-assassination/?xid=whatsappshare (accessed January $28,2017)$ 
rapprochement accelerated, again and it may become the ultimate level rapprochement between two countries. Astana talks has occurred after Moscow summit and declared ceasefire between Syrian government and opposition. Turkey and Russia will stand a guarantor of ceasefire.

Turkish-Russian relations experienced top and bottom in one year. On the other hand, the new president of the United States, Donald J. Trump and Russian leader Vladimir Putin's intimacy and deal for coordinating each other's power against ISIS will be end of the ISIS. Indeed this intimacy is very important for Turkey under this conjuncture for the following question: How Syria will be reconstructed, is it going to include any Kurdish State or will it follow a federation. 